\title{
UM ESQUELETO NUM CAVALO BRANCO
}

Raquel Belisario da Silva

Recebido em 02 nov 2020. Raquel Belisario da Silva é doutora e pesquisadora Aprovado em 16 dez 2020.

dos grupos de pesquisa Cartografias Narrativas em Língua Portuguesa: redes e enredos de subjetividade e A Tradução Literária no Rio Grande do Sul. http://lattes.cnpq.br/0442245051456235 http://orcid.org/0000-0001-9222-4279 raquel.belisario@gmail.com

Resumo: O presente artigo propõe analisar a peça A doença branca, do escritor tcheco Karel Čapek, publicada e encenada pela primeira vez no ano de 1937. Será considerada a situação política europeia naquele período, bem como o reflexo, dentro da obra, do pensamento e das opiniões do autor sobre tal situação. Como aporte teórico, o texto trará a contribuição de Susan Sontag, que se dedicou a escrever sobre a doença enquanto metáfora, inclusive na literatura. Além disso, estudos dedicados à vida e à obra de Čapek comporão um quadro mais geral sobre o qual se poderá apoiar a apreciação desse drama específico. Busca-se, com isso, partir do exame do drama selecionado, e de como o autor aborda o tema da doença, para pensar a atualidade dessa leitura no momento em que o mundo, uma vez mais, é atingido por uma pandemia.

Palavras-chave: Doença e Literatura. Política e Literatura. Literatura Tcheca. Karel Čapek. 
Abstract: The aim of this paper is to analyze The White Plague, by Czech writer Karel Čapek, a play that was first published and staged in 1937. The European political situation in that period will be considered, as well as the repercussion of the author's thoughts and opinions about this situation within his work. As theoretical support the text will bring Susan Sontag's writings Illness as Metaphor and Aids and its Metaphors. Furthermore, some studies dedicated to the life and work of Karel Čapek will compose a general framework on which the comments on that specific play can be supported. Thereby, based on a careful examination of this selected drama, and also on how the author approaches the theme of illness in his work, we seek to think about the relevance of this reading at a time when the world, once again, is hit by a pandemic.

Keywords: Illness and Literature. Politics and Literature. Czech Literature. Karel Čapek.

"Prefiro deixar morrer morféticamente um mundo inteiro do que aturar, por um só momento, a sua lepra pacifista." Sigelius, ČAPEK, 1942, p. 49

"Então você pensa que depois de empatar milhares de contos em armamentos pode alguém firmar uma paz eterna?" Pai, ČAPEK, 1942, p. 55

"Era uma vez uma cidade. E eu a cavalo, há muito tempo sem carne, que apodreceu... só me restarão olhos, sempre na frente dos soldados... um esqueleto num cavalo branco... E o povo gritará: Viva o Marechal!" Marechal, С̌APEK, 1942, p. 88-89 


\section{INTRODUÇÃO}

Na ficção, a doença como epidemia ou como marca de um indivíduo isolado está presente desde os primeiros textos conhecidos, desempenhando papéis que variam entre a punição exemplar ou castigo coletivo, a força motora da narrativa ou o motivo de peripécias e reviravoltas. A discussão aqui proposta abordará a obra um pouco esquecida (porém, revivida neste ano em que uma pandemia atinge cifras de milhões de mortes) $A$ doença branca, de Karel Čapek, e se deterá nos usos que o autor faz da doença, seus sintomas e possibilidades de tratamento, dentro de um contexto de pré-guerra, atmosfera política e científicotecnológica na qual estava inscrita a Tchecoslováquia em 1937, quando a peça veio a público. Escritos de Susan Sontag sobre a presença da doença no texto literário e seu uso como metáfora terão o importante papel de conduzir uma discussão nesse sentido, enquanto pesquisas dedicadas à obra e à vida do escritor tcheco trarão aspectos relevantes para a apreciação do drama $A$ doença branca como parte de um conjunto coeso dentro da produção escrita, ficcional e não ficcional, de Čapek.

\section{KAREL ČAPEK}

Mais conhecido entre os leitores brasileiros por suas Kniha apokryfů (publicado em português como Histórias Apócrifas, 2013) ou pela difusão do termo robô, utilizado em sua peça R.U.R. Russomoví univerzálni roboti (no Brasil, publicada como A fábrica de robôs, 2010), Karel Čapek foi um autor de muitos gêneros, e em todos eles, aprofundou discussões sobre os acontecimentos de seu tempo, uma era de grandes transformações no território 
da Boêmia. Quando nasceu, em 1890, o território ainda fazia parte do império Austro-Húngaro, e a língua tcheca mantinha-se como registro de uma minoria, sendo o alemão a língua principal da cultura. Ao morrer, em dezembro de 1938, o autor havia visto seu país - a Tchecoslováquia, brevemente conhecida como uma ilha de democracia exemplar na Europa pós-Primeira Guerra - ser recémdividido pelo tratado de Munique; parte tcheca recairia nas mãos dos nazistas, como um protetorado.

Karel Čapek envolveu-se com assuntos políticos muito cedo, participando de uma sociedade secreta anarquista ainda aos quinze anos, motivo de ter sido expulso da escola na cidade de Hradec Králové, onde morava, e passar a estudar primeiro em Brno e depois em Praga. Também desta época datam seus primeiros escritos conhecidos - alguns poemas publicados ainda em 1904. Na Universidade Carlos, em Praga, inicia, em 1909, estudos que incluem Filosofia, Estética, História das Artes Plásticas, bem como Letras germânicas, inglesas e boêmias. Por breves períodos, estuda também em Berlim e Paris, acompanhado pelo irmão Joseph Čapek, figura importante em sua vida e colaborador em sua obra, fosse como ilustrador, coautor ou no debate de ideias. Em 1915, Karel Čapek conclui seus estudos acadêmicos com a tese Objektivní metoda $v$ estetice se zřetelem $k$ výtvarnému umění ( $O$ método objetivo da Estética aplicado às Artes Plásticas). Poucos anos mais tarde, publica um ensaio intitulado Pragmatismus čili Filozofie praktického života (Pragmatismo, ou Filosofia para a vida prática), e muitos estudiosos (entre eles o escritor Ivan Klíma, que se dedicou à escrita de uma biografia de Čapek) veem em sua obra reflexos 
do pragmatismo tanto quanto uma mudança de perspectiva filosófica em seus últimos anos de vida:

Čapek elaborou um artigo bem fundamentado sobre pragmatismo, o qual foi publicado em 1918 como Pragmatismo, ou Filosofia para a Vida Prática. Não foi um ensaio muito longo, mas não podemos deixá-lo passar por uma razão muito simples: Čapek aceitou os princípios básicos de sua filosofia e, por quase sua vida inteira tirou deles a forma de resolver os fundamentais problemas sociais e humanos sobre os quais escreveu tão urgentemente. (KLIMA, 2002, p. 41, tradução nossa) $)^{1}$

Jornalista, dramaturgo, escritor de contos, histórias infantis, alguns romances e livros de viagem, tradutor de poesia francesa para o tcheco, interessado nas artes plásticas tanto quanto na jardinagem, amigo de grandes figuras políticas de seu país e estrangeiros notáveis da literatura, Karel Čapek teve ainda em vida o reconhecimento por seu trabalho e por suas reflexões sobre as circunstâncias contemporâneas da Europa nas décadas de 1920 e 1930. Foi o primeiro presidente da seção tcheca do PEN Club, em cuja fundação teve colaboração fundamental; tal posição, que ocupou de 1925 até 1933, permitiu-Ihe viajar por diversos países, por onde fazia novos contatos e difundia publicamente seu pensamento pacifista bem como alertas para a ameaça de guerra iminente. Reunia em sua casa, no chamado "clube das sextasfeiras", representantes da diversidade intelectual e artística tcheca.

1 Conforme obra consultada em inglês: "Čapek prepared a well-grounded paper on pragmatism, which was published in 1918 as "Pragmatism, or a Philosophy for a Practical Life." It was not a very long essay, but we cannot pass it by for one very simple reason: Čapek accepted the basic tenets of this philosophy, and for nearly his entire life deduced from them a way of solving the fundamental social and human problems about which he wrote so urgently." 
Em um desses encontros, conheceu o presidente Tomáš Garrigue Masaryk, com quem estreitou laços que resultariam, inclusive, na publicação de quatro livros de entrevistas. Nas palavras do tradutor e pesquisador Aleksandar Jovanović:

Homem de pensamento livre, de bons costumes, tornou-se o máximo representante da cultura democrática de seu país, advertindo os compatriotas e o mundo a respeito do perigo dos fundamentalismos ideológicos, que varreriam a democracia e a cultura humanística tanto do Velho Continente quanto de qualquer outro ponto no mapa-múndi. (JOVANOVIC, 2010, p. 11)

Através das palavras, sua luta contra o fascismo - e mais diretamente contra os rumos que tomava a Europa centro-oriental na década de 1930, com ascensão do nazismo na Alemanha rendeu-lhe admiração e inimizades. Indicado seis vezes ao prêmio Nobel de literatura, nunca chegou a ser laureado; e a versão aceite para não ter sido escolhido, segundo os comentaristas de sua vida e obra, baseia-se no fato de que a Academia Sueca tinha medo de entrar em conflito com as forças crescentes do nazismo. Entretanto, Čapek parecia cada vez mais empenhado em impedir que o discurso fascista ocupasse as mentes tchecas.

Com a deterioração da situação política em toda a Europa, a opinião pacifista de Čapek na segunda metade da década de 1930 se transformou em uma determinação de enfrentar o mal. Esse esforço se refletiu nas atividades jornalísticas e autorais. As obras mais famosas que alertam para o perigo iminente incluem o romance $A$ guerra das salamandras (1936) e os dramas $A$ doença branca (1937) e $A$ mãe (1938). Além de sua obra literária, 
Karel Čapek esteve envolvido na luta antifascista, por exemplo, como signatário de declarações que condenavam o fascismo. (JíCHOVÁ, 2016, p. 19, tradução nossa) ${ }^{2}$

Não só a situação política de sua época, mas também os avanços da ciência no início do século $X X$, em especial possíveis abusos na manipulação da tecnologia e sua glorificação sobre o humano, foram tema recorrente na obra de Karel Čapek e uma preocupação constante em seus debates intelectuais. Da mesma forma, os discursos que influenciavam a opinião pública, sobretudo o jornalístico e o político, e a maneira como os valores humanos podem ser relativizados diante de situações extremas, como a guerra ou uma epidemia, não escaparam à sua observação artística de base filosófica. Segundo Petr Jemelka, que analisa os temas da bioética na obra literária de Čapek, o autor "evidentemente seguiu ambos os desenvolvimentos na ciência entreguerras, o tcheco e estrangeiro" (2019, p. 172) ${ }^{3}$. E, no entanto, ele comenta:

De qualquer maneira, Čapek não abandonou sua imaginação a excursões vagas e expansivas, mas está sempre bem fundamentado na forma real e na direção da pesquisa e do desenvolvimento técnico. Desse modo, ele trabalha sobre questões já levantadas pela ciência. Ainda assim, ele não para por aí; suas obras não estão engajadas por sua visão futurística no estilo de Júlio Verne.

2 Do original, em tcheco: "Se stále se zhoršující politickou situací v celé Evropě se Čapkův názorový pacifismus v druhé polovině třicátých let přetavil v odhodlání postavit se zlu. Tato snaha se projevovala jak publicistickou činností, tak činností autorskou. Mezi nejznámější díla varující před blížícím se nebezpečím patří román Válka s mloky (1936) a dramata Bílá nemoc (1937) a Matka (1938). Mimo literární tvorbu se Karel Čapek v boji proti fašismu angažoval např. i coby signatář prohlášení odsuzujících fašismus".

3 Do original, em inglês: "[...] Capek also evidently followed developments in interwar science, both Czech and foreign". 
As obras (não apenas) utópicas de Čapek apresentam questões significantes, essencialmente morais - valores humanos, as possibilidades e limitações da liberdade e tomada de decisão, e sempre o eterno custo da vida. (JEMELKA, 2019, p. 173 , tradução nossa) ${ }^{4}$

Na peça A doença branca (1942), como veremos adiante, além do alerta contra os horrores da guerra, há ainda uma discussão ética sobre procedimentos científicos e publicidade de novas descobertas; e uma discussão moral, a respeito da liberdade de escolha que envolve a manutenção de vidas humanas.

\section{A DOENÇA BRANCA}

O drama A doença branca, de 1937 (aqui será analisada uma tradução para o português de 1942), foi um dos últimos trabalhos publicados em vida por Karel Čapek. Após dez anos sem escrever para teatro (a última peça havia sido Adam stvořitel - Adam, o criador - de 1927), devido ao clima de terror que se espalhava pela Europa, o autor resolveu manifestar-se através do drama, possivelmente como forma de dirigir-se de maneira mais direta ao público tcheco e estrangeiro. Logo após sua estreia em Praga, em 29 de janeiro de 1937, e antes do início da guerra, A doença branca foi encenada em diversos estados democráticos da Europa e América do Sul, e também nos EUA, sendo recebida com entusiasmo inclusive por escritores como Thomas Mann, que escreveu uma carta ao autor,

4 Do original, em inglês: "However, Capek did not abandon his imagination for vague and expansive excursions, but is always well grounded in the real form and direction of research and technical development. He thus elaborates on questions already raised by science. Yet he does not stop there; his works are not engaging for their futuristic view in the style of Jules Verne. Capek's (not only) Utopian work presents significant, primarily moral, questions - human values, the possibilities and limitations of freedom and decision-making and always the eternal cost of life". 
parabenizando-o por sua "audácia e uso de recursos teatrais" bem como pela "ficção e simbolismo da peça" (JíCHOVÁ, 2016, p. 22-23).

No "Preâmbulo" à obra, que infelizmente não consta da edição traduzida ao português, Čapek explana as condições de criação que denotam a urgência do tema desenvolvido:

O primeiro estímulo para esta peça, anos atrás, deu-me a ideia um médico, amigo do Dr. Jiři Foustka: um médico descobre novos raios que destroem cânceres, e encontra entre eles os raios da morte; com a ajuda dos raios, ele se torna um autocrata e não o piedoso salvador do mundo. A ideia de um médico que, à sua maneira, tem o destino da humanidade em suas mãos, ficou comigo a partir de então. Mas no nosso tempo são tantas as pessoas que têm ou querem ter nas mãos os destinos das nações ou da humanidade, que nunca me motivaria a reproduzir outra cópia, se não houvesse um segundo estímulo mais convincente: esse é o nosso próprio tempo. (ČAPEK, 2018, p. 8, tradução nossa) ${ }^{5}$

No drama, a "doença branca" é conhecida popularmente como "lepra de Peipin" (ČAPEK, 1942, p. 14) e atinge pessoas com mais de quarenta e cinco anos, levando-as à morte rapidamente. Quase três anos após o primeiro caso na Europa, os médicos mais renomados, como o conselheiro Sigelius, ainda não sabem como curar a doença e, por isso, tratam seus pacientes apenas com sedativos para a dor e desinfetantes para o mau cheiro.

5 Do original, em tcheco: "První podnet k této hre dal mi pred léty námet prítele lékare dr. Jirího Foustky: doktor, který objeví nové paprsky, nicící zhoubné nádory, najde v nich paprsky smrti; jich pomocí se stane samovládcem a neblahým spasitelem sveta. Z toho námetu mi utkvela predstava lékare, který má svým zpusobem v rukou osud lidstva. Ale za našich casu je tolik lidí, kterí mají nebo chtejí mít v rukou osudy národu nebo clove censtva, že by me nikdy nezlákalo rozmnožit je ješte o jeden exemplár, kdyby tu nebyl druhý a nutkavejší podnet: tím je naše doba sama". 
Após um primeiro quadro muito rápido, em que três doentes, os três lázaros, conversam sobre a doença, tentando decifrar em que ela consiste - uma peste? um castigo divino? -, no segundo quadro do primeiro ato, o conselheiro Sigelius, através de dois diálogos consecutivos (um com um jornalista e outro com o doutor Galen), nos fornece os detalhes sobre a doença:

Jornalista: Quer dizer: - é uma doença mais séria do que a lepra?

Sigelius: Sem dúvida. Muito mais séria e mais interessante. Apenas os primeiros sintomas nos fazem lembrar a lepra: uma insignificante mancha branca em alguma parte da superfície do corpo, fria como mármore, sem sensibilidade e alheia ao tacto, chamada por isso "mácula marmórea"; este é o motivo porque esta enfermidade também se chama doença branca. Mas o seu curso é muito original e absolutamente diferente da "leprosis maculosa" comum. Nós a denominamos simplesmente a doença de Tcheng ou "morbis Tchengui". O Dr. Tcheng, discípulo de Charcot, naturalmente especialista em doenças internas, descreveu-a pela primeira vez em alguns casos observados no Hospital de Peipin. Magnífica publicação, amigo; citei-a já no ano de 23 , quando ninguem sonhava que a doença de Tcheng chegaria a ser uma pandemia.

Jornalista: Chegaria a ser o que?

Sigelius: Pandemia. Doença que ameaçará o mundo inteiro. Na China, amigo, surge quasi anualmente uma nova doença interessante - isso devido à pobreza - mas nenhuma alcançou o vulto da doença de Tcheng. Essa é a doença de hoje. Até o presente, mais de cinco milhões de almas pereceram com ela, mais de doze estão atualmente 
afetadas por ela e mais do que o triplo desta cifra anda pelo mundo ignorando que já tem no corpo uma pequena mancha marmórea e insensível, menor do que um feijãozinho... - E ainda não decorreram três anos desde o aparecimento desta doença entre nós. (ČAPEK, 1942, p. 15) ${ }^{6}$

Como podemos ver, alguns elementos a serem discutidos na peça já se mostram nesta citação - um pouco longa, mas necessária. Depois de passar essas informações ao jornalista, e ainda outras para que ele divulgue que a renomada clínica do Dr. Liliental está trabalhando ativamente para conter a doença - embora não tenha encontrado nem cura nem prevenção -, o conselheiro Sigelius conversa com o Dr. Galen, que diz ter descoberto uma possível cura. Sigelius atende-o, porém se mantém desconfiado e contestando todos os argumentos de Galen, até que finalmente é convencido a deixar que ele aplique seu método na ala dos pobres da clínica. Dr. Galen impõe apenas uma condição: terá de trabalhar sozinho, sem nunca divulgar a ninguém seus procedimentos.

Uma das discussões que se pode notar ainda no primeiro ato, mas que parece não ser estendida, é a ideia do local versus o estrangeiro, implicada de forma explícita em poucas passagens. A primeira aparece na cena citada acima: a doença vem da China, como acontece com regularidade - ou seja, a doença vem de fora. Segundo Susan Sontag, em A Aids e suas metáforas: "A ideia de que as doenças que afligem a Europa vêm de fora faz parte da secular imagem da Europa como entidade cultural privilegiada. Pressupõe-se a Europa, de direito, isenta de doenças" (SONTAG, 2007, posição 1628).

6 Respeitada a ortografia do texto consultado em todas as citações desta tradução. 
Essa ideia de superioridade diante de outros povos é tão profundamente inculcada na população - pelas autoridades e pelos meios de comunicação -, que Čapek dispõe adiante, no terceiro quadro do primeiro ato, uma cena em família, com uma das falas do pai sendo mais direta em suas opiniões preconceituosas e desinformadas sobre a China:

Pai: [...] - Interessante, diz aqui o Sigelius que esta doença veio da China. Está vendo, eu sempre digo: o melhor seria fazer da China um protetorado, impor a ordem e assim haveria socêgo no mundo. É o resultado de se tolerar ainda êsses países atrasados. Só há fôme e miséria, nenhuma higiene e depois vem a lepra. (ČAPEK, 1942, p. 28)

As conversas entre os integrantes dessa família, ao longo da peça, costumam mostrar o reflexo das decisões tomadas pelas autoridades políticas e científicas, bem como dos discursos oficiais difundidos pela imprensa, na vida cotidiana de uma família que, nos dias atuais, poderia equivaler à "classe média". O pai trabalha há trinta anos nas Usinas Krug - que produz materiais bélicos - $\mathrm{e}$, por conta da pandemia que levou à morte cinco de seus colegas do mesmo setor, torna-se "diretor de contabilidade", agradecendo à doença branca pelo seu sucesso; a mãe é uma dona de casa conciliadora, que se preocupa com os doentes e questiona a guerra, mas acaba por acatar as ideias do marido e ser vitimada pela doença de Tcheng; o filho e a filha, desocupados, passam a ver perspectivas de futuro para os jovens com a morte das pessoas acima dos cinquenta anos. Pai e filho, patriotas, entusiasmam-se com a proximidade da guerra a ponto de não lhes importar que quaisquer males advenham também à própria família e à nação. 
Outra passagem pertinente ao tema da superioridade nacional está na conversa entre os dois médicos, quando o Dr. Sigelius argumenta não poder admitir um estrangeiro na clínica. Com a contra argumentação do Dr. Galen, um grego, de que o próprio fundador da clínica era um estrangeiro, o conselheiro defende Liliental (um nome alemão, embora não seja mencionada a origem do próprio homem), seu sogro, dizendo que os tempos são outros. Sutilmente, o que Čapek está dizendo aqui é que não se vive mais na antiguidade clássica em que gregos gozavam de direitos e reputação diante de outros povos, por conta de sua afamada democracia; no tempo europeu pós-Primeira Guerra, os alemães se impõem. Mais adiante, Sigelius ainda vai acusar Galen de, por ser de origem estrangeira, não poder "ter uma noção exata sobre o futuro" da sua raça (ČAPEK, 1942, p. 48).

Dr. Galen vem da cidade de Pérgamo, antigamente território grego, hoje parte da Turquia. Čapek faz aqui uma referência ao estudioso da medicina Claudius Galenus (ou Galeno de Pérgamo), que atuava em Roma no final do século II e início do III. Durante o período de guerras dos romanos em terras estrangeiras, Galeno, que havia deixado Roma sob ameaça de morrer nas mãos de outros médicos dos quais divergia (por acreditar na observação continuada dos pacientes ao invés de pensar dentro do padrão de cuidado da época, baseado em misticismo e adivinhação), foi chamado de volta para ajudar a combater uma praga que se alastrou no Império. Não é a primeira vez que Čapek recorre à Antiguidade para nomear suas personagens. Em A fábrica de robôs, de 1920 (TCHÁPEK, 2010), além da própria Helena, que conquista todos os homens da fábrica quando chega, e 
sua extensão - a robô Helena, que se humaniza através dos sentimentos -, há ainda os robôs Primus, Radius, Marius e Sulla, esta última erroneamente batizada, segundo a Helena humana, pois trata-se do nome de um general romano e não deveria ser utilizado para nomear uma robô feminina.

Após essa pequena digressão, voltemos ao texto de $A$ doença branca. Se continuarmos acompanhando o pensamento de Sontag, apesar de termos dito antes que o debate sobre o estrangeiro aparentemente não se estende, podemos inferir que, de alguma maneira, ele continua, porém, submerso pelos debates moral e ético da detenção do poder sobre a vida e a morte de milhares de pessoas. Para a filósofa, "O fato de a doença ser associada aos pobres - os quais são, para os privilegiados, estranhos vivendo no meio deles - reforça a associação com o estrangeiro: com um lugar exótico, muitas vezes primitivo" (SONTAG, 2007, posição 1650). No drama de Čapek, quando Sigelius concorda com a proposta de Galen, para desenvolver em sua clínica, em segredo, um tratamento que cure a doença de Tcheng, o conselheiro designa como "laboratório" a ala destinada ao atendimento dos pobres:

Primeiro Assistente (entrando): O Sr. conselheiro chamou-me?

Sigelius: Sim, venha cá. Em que secção temos "Morbus Tchengui"?

Pr. Ass.: Em quasi todas, senhor conselheiro, segunda, quarta, quinta.

Sigelius: E os que não pagam?

Pr. Ass.: Estes estão na décima terceira.

Sigelius: Com quem está isso? 
Pr. Ass.: Com o segundo assistente.

Sigelius: Bem, neste caso, diga ao segundo assistente que de hoje em diante o tratamento, as receitas e aplicações na trese serão feitas pelo Dr. Galen. Serão casos dele. (ČAPEK, 1942, p. 26)

Um outro ponto em que o tema do estrangeiro está presente nas entrelinhas é na situação de guerra vivida pelo país não nomeado em que o drama se desenrola. Nessa situação, contudo, o estrangeiro é apenas um alvo abstrato, não sendo relevante a nacionalidade do inimigo; o que importa é evitar as negociações de paz a qualquer custo e fazer a guerra apenas porque, diz o Marechal: "Jamais encontraremos melhor oportunidade" (ČAPEK, 1942, p. 80). Depois de ter iniciado a guerra com um ataque surpresa, o Marechal discursa da varanda de sua sala de trabalho, no terceiro ato, justificando suas decisões e recebendo apoio do povo que se aglomera na rua. Os termos com que se refere ao país atacado denotam o descaso com o outro, tanto quanto a estratégia discursiva de despersonalizar e desmoralizar o inimigo, conforme podemos ver na passagem abaixo:

Marechal (Discursando): [...] Sim, começamos a guerra e a começamos sem a declaração; fiz assim para poupar a vida de milhares de nossos jovens soldados, que agora ganham a nossa primeira batalha, antes que o inimigo possa reagir da sua estupefação. Agora, quero do meu povo a aprovação deste meu passo. - (Gritaria frenética: Sim, sim, viva o Marechal!). - Comecei essa guerra sem qualquer negociação humilhante com esse pequeno povo, que pensa poder provocar e ofender sem castigo a nossa grandiosa nação, - (gritos de descontentamento). - e por meio de bandidos 
pagos para agredir a nossa ordem e segurança. (Gritaria: Matar. Pendurar. Traidores.) Silêncio. Com gritos não afastaremos o mal. Só existe um caminho: destroçar com rapidez êsse minúsculo Estado, que continuamente ameaçou a nossa paz; aniquilar essa nação inferior, que não tem direito a viver, seja ela protegida por quem for. E agora, que as outras potências ponham as cartas na mesa. Não temos medo de ninguem. (ČAPEK, 1942, p. 8182 , grifos nossos)

Nem nesse discurso nem em qualquer outro momento, sabemos que nação é essa que se impõe pela força, e menos ainda sabemos a respeito do Estado que é seu "inimigo". Embora Čapek propositadamente tenha deixado de nomear também o país onde se passa o drama, ele vincula essa nação soberana ao status europeu de país desenvolvido - quer no orgulho do conselheiro Sigelius diante de suas pesquisas infrutiferas sobre a doença de Tcheng, quer na defesa que o pai faz da nação quando a mãe se opõe à guerra, ou ainda nas falas do Marechal e seus subalternos. Já o país inimigo, seja ele qual for, é um minúsculo Estado, uma nação inferior que precisa ser protegida por outras potências.

\section{TEMÁTICA CONTEMPORÂNEA E ATEMPORAL}

Em um breve comentário sobre o drama A doença branca, Susan Sontag diz que "a peça alegórica de Čapek é uma anomalia: a utilização da metáfora da peste para exprimir a ameaça do que é definido como barbárie por um liberal europeu tradicional" (2007, posição 1721). Entretanto, acrescenta:

Mas Čapek não está interessado em identificar o mal político com a incursão do estrangeiro. $O$ didatismo da peça baseia-se não na doença em si, mas no modo 
como os cientistas, jornalistas e políticos controlam as informações. [...] Por mais primária que seja a ironia de Čapek, sua visão de uma catástrofe (médica, ecológica) como evento público administrado pelas autoridades numa sociedade de massas moderna está longe de ser inverossímil. (SONTAG, 2007, posições 1721-1727-1734)

Lendo o drama de Čapek e as anotações de Sontag, a partir da situação de pandemia que está sendo vivida em 2020, percebemos que a filósofa não podia estar mais certa sobre a verossimilhança na obra do autor, ainda que ambos não tenham presenciado a era da pós-verdade e das fake news.

Na peça, o conselheiro Sigelius, que chefia a clínica Liliental, referência de pesquisas em saúde, está pouco interessado em curar seus pacientes. Seu declarado amor pela pesquisa científica busca a fama e o prestígio vinculados às descobertas de importância internacional. Nas entrevistas com jornalistas, ele se ocupa de privilegiar a divulgação de informações que considera importantes para o conhecimento do público, ainda que grande parte delas não seja relevante para encontrar a cura ou mesmo uma forma de prevenção. Ele também decide quais informações são desnecessárias ou poderiam causar pânico e, por isso, não devem ser divulgadas. Às voltas com seus artigos e publicações médicas, entrega os cuidados com os pacientes aos seus assistentes e ao Dr. Galen, enquanto articula a publicidade e a política de atender não os mais necessitados, mas justamente os mais abastados e bem relacionados: "No fim de contas, estamos aquí para suavizar os sofrimentos - ao menos dos clientes que pagam" (ČAPEK, 1942, p. 20). 
Já o Dr. Galen, com sua descoberta de um tratamento que pode levar à cura na maioria (em torno de sessenta por cento) dos casos, busca a paz mundial. Tendo garantido o sucesso de seu método no trato de pacientes em uma clínica de renome, tudo o que ele almeja é alcançar a razão dos poderosos e fazê-los desistir da guerra. Para isso, ele tenta convencer os jornalistas a tornarem pública sua mensagem; todavia, Sigelius o expulsa da clínica. Sua luta pelo fim da guerra esbarra, ainda, na falta de recursos financeiros para bancar uma campanha maciça de publicidade pacifista. Dessa forma, tudo que ele pode fazer é recusar-se a tratar qualquer pessoa que tenha condições de pagar por um tratamento, a menos que o doente concorde em ajudá-lo a evitar a guerra.

$\mathrm{O}$ conde Krug, dono das usinas que fabricam tanques de guerra tanto para seu país quanto para outras potências, chega a repensar seu posicionamento quando descobre estar infectado; mas, ao perceber que não conseguirá nem convencer o Marechal a cessar os preparativos para a guerra, nem convencer o Dr. Galen a cuidar do seu caso, suicidase. Já o pai de família, que ascendeu à direção de contabilidade das usinas, recusa-se a abrir mão de sua posição para tentar salvar a esposa contaminada. O Marechal ainda vai mais longe: ao descobrir-se doente, insiste na guerra a qualquer custo. $\mathrm{E}$ quando seu assistente, sobrinho do conde Krug, telefona para o Dr. Galen pedindo atendimento ao Marechal, este ainda se recusa de maneira obstinada:

Marechal: (pula): Não, não e não. Não quero a paz. Tenho que guerrear. Não posso revogar as ordens. Não posso admitir que me rebaixe assim. Você ficou louco, Paulo. Precisamos ganhar esta guerra. A razão está conosco, estamos com o direito!

Krug: Não estamos com o direito, Marechal... 
Marechal: ... Eu sei que não estamos, rapaz, mas quero que a minha nação vença. A minha pessoa não tem importância. Em nome da nação, desligai. Desligai, Paulo, eu posso... morrer pelo bem da nação. (ČAPEK, 1942, p. 90)

Os delírios de grandeza do chefe militar, no entanto, são vencidos pela argumentação de Paulo. Isso, porém, não evita a continuidade da guerra, nem o final trágico, pois a multidão enfurecida que brada do lado de fora da janela do Marechal impede a chegada do Dr. Galen, o pacifista, ao seu destino. O médico é morto pela turba ensandecida, e o militar não receberá os cuidados de que precisa; assim, nenhum deles poderá mais impedir o avanço da guerra.

Nesta peça, Čapek já não apela mais ao pragmatismo como solução, conforme destacou Klíma (citado anteriormente). E Jana Jíchová demonstra em sua tese que, a partir da década de 1930, é possível notar uma mudança maior de opinião refletida na ficção de Čapek - incluído aí o drama A doença Branca -, que o leva a não mais colocar o dever acima da consciência ou dos sentimentos humanitários. A pesquisadora aponta que:

[...] quando em conexão com a situação política e social constantemente agudizada, ele parece abandonar sua visão de compromisso e, com uma ênfase crescente no apelo moral, orienta seus textos em uma direção antifascista. Foi o advento do fascismo que obrigou Čapek a reconsiderar seus pontos de vista, a abandonar a busca pela harmonia e a se definir e se engajar ativamente devido à necessidade de defender a democracia, a liberdade e a república. (JíCHOVÁ, 2016, p. 36)7

7 Conforme o original, em tcheco: "Celkově se dá říct, že ve třicátých letech dvacátého století dochází u Čapka k většímu názorovému posunu, když v souvislosti s neustále se vyostřující politickou a společenskou situací zdánlivě opouští svou vizi kompromisu a 
É possível visualizar tal mudança de perspectiva na personagem Dr. Galen, que, como médico, estaria obrigado a colocar seu dever acima de qualquer ideal, por mais humanitário que fosse, atendendo os pacientes sem distinção de classe social e sem impor condições. Ele é confrontado em suas decisões desde o início, em ataques de involuntária ironia do conselheiro Sigelius, que o acusa de não querer dividir o resultado positivo das suas pesquisas nem o método de tratamento com o restante da comunidade médica a fim de obter apenas para si as glórias que sua descoberta poderia trazer.

Embora à primeira vista possa parecer que o conselheiro é mais consciente do que Galen a respeito do seu dever de médico, o diálogo que encerra a parceria entre eles deixa bastante claro o contrário:

Sigelius: Ou o senhor é maluco ou é um miserável traidor da pátria, Galen. Exijo que se porte como médico. Sua obrigação é ajudar os doentes; o resto não pode interessar-lhe, ouviu?

Galen: Mas como médico desejo que os homens não se matem em guerras...

Sigelius: Mas no meu Instituto, proíbo-lhe falar sobre esses desejos. Nós aqui não somos servidores da humanidade e sim da ciência - e servidores da nação, senhor colega. É favor não se esquecer que esta é uma instituição do governo. (ČAPEK, 1942, p. 48)

Eis aí o retorno de Čapek a um de seus temas favoritos: os interesses da ciência. E, como saúde e ciência são dois temas de opustit snahu o harmonii, a z důvodu potřeby obrany demokracie, svobody a republiky se vymezit a aktivně angažovat". 
atualização constante, podemos usar a peça do escritor tcheco, de quase um século atrás, para pensar também o nosso momento atual. Servir à ciência requer deixar a humanidade em segundo plano? A ciência está desvinculada de temas sociais e políticos? Ou da vida? Os interesses da nação não passam pelo desenvolvimento de uma ciência que possa ser aplicada à solução de problemas do cotidiano do seu povo, como a saúde?

No terceiro quadro do segundo ato, o conselheiro Sigelius conta ao conde Krug sua nova ideia para o tratamento dos doentes da lepra de Peipin: campos de concentração, pois é preciso "diminuir a possibilidade de contágio ao mínimo. Qualquer sentimentalismo seria crime. Quem procurar fugir será fuzilado" (ČAPEK, 1942, p. 62). Ao final deste diálogo, o conde Krug recebe o diagnóstico positivo para a doença. E, mesmo sabendo que ele próprio pode ir parar em um desses campos de concentração, despede-se do conselheiro dizendo que precisa aumentar a produção de arame farpado em suas fábricas, já que o isolamento será decretado em breve. Essa conversa entre as duas personagens impõe mais alguns questionamentos, bastante atuais em tempos de covid-19: como se decide qual vida tem mais valor - a do doente ou a do são? Quais os limites da interferência do poder público na vida dos cidadãos? O investimento em material bélico (lembrando que as Usinas Krug produzem também tanques de guerra e munição) e de contenção (arame) é mais importante para uma nação do que investir na busca pela cura de uma doença que se alastra rapidamente?

No sexto quadro do segundo ato, o autor foi ainda mais didático e direto ao abordar os meios pelos quais um discurso oficial se torna o desejo do povo e, em uma típica tautologia, 
alimenta a retórica da política como uma missão elevada, a missão de guiar o povo em busca dos seus objetivos. A conversa entre Dr. Galen e o Marechal, quando este ainda tentava convencer o médico a tratar do conde Krug, funciona basicamente como um diálogo platônico, sobretudo quando o militar tenta explicar os motivos pelos quais não pode desistir da guerra e o médico grego tenta, sem sucesso, direcionar seu interlocutor a uma mudança de perspectiva:

Marechal: [...] Sou obrigado a defender os interesses da nação. Se o meu povo deve entrar na guerra, meu dever é educá-lo para a guerra...

Galen: Porém, se não fôsse o senhor, provavelmente o seu povo não pensaria em guerras, não é?

Marechal: Não pensaria e nem poderia pensar, pois não estaria preparado para isso. Êle assim não conheceria a própria força e desconheceria as possibilidades. Hoje, graças a Deus, já as conhece... e eu apenas cumpro a sua vontade...

Galen: ... que o senhor mesmo criou.

Marechal: Sim. Eu fiz nascer nêle a vontade de viver. Você pensa que a paz é melhor do que a guerra. Porém, tenho certeza de que uma guerra vitoriosa é melhor do que a paz. E eu não posso privar o meu povo dessa vitória. (ČAPEK, 1942, p. 75-76)

Já no início do terceiro ato, em cujo cerne estão a figura do Marechal e suas decisões sobre a guerra, Čapek traz o debate da publicização de informações para o âmbito da manipulação das massas através de canais do governo, como o Ministério da Propaganda. Nesse ponto, advertido de que o povo, por medo da doença, já não fala com o mesmo entusiasmo sobre a guerra, 
e até mesmo prefere a "a saúde aos louros da glória" (ČAPEK, 1942, p. 80), o Marechal urde o ataque que desencadeará os primeiros embates.

No quadro seguinte, porém, quando o militar descobre que está contaminado, percebe também que não tem mais poder sobre o desenrolar dos fatos: a guerra, depois de iniciada, foge de seu controle. Assim, o bravo Marechal - que, nas palavras de Sigelius, é "o maior médico de todos os tempos, que com sua salvadora terapêutica, enérgica e às vezes cirúrgica, destruiu a raiz da morféia nacional" (ČAPEK, 1942, p. 41) - agora está impotente diante da situação criada por ele mesmo.

Sobre a utilização da doença enquanto metáfora, a análise de Sontag sobre a peça está bastante afinada com os demais estudiosos de vida e obra do dramaturgo. Segundo seu comentário, a utilização que o autor faz da metáfora da doença como um castigo - que não poupa nem mesmo o destemido Marechal -, embora seja convencional, demonstra a profunda percepção de Čapek sobre as relações públicas (SONTAG, 2007, posição 1734). De fato, podemos dizer que, neste drama, Karel Čapek parece ter mobilizado não apenas seu conhecimento adquirido em anos de jornalismo opinativo e informativo, como também o que aprendeu na convivência com representantes das diversas esferas sociais, como médicos e políticos.

\section{CONSIDERAÇÕES FINAIS}

Conforme nos diz Susan Sontag, em Doença como metáfora: "As enfermidades sempre foram usadas como metáforas com o intuito de reforçar as acusações de que uma sociedade era corrupta ou injusta" 
(2007, posição 866). E anos depois, retomando o tema em AIDS e suas metáforas, informa ainda que na década de 1930, a metáfora da peste era comumente utilizada nas artes para representar "catástrofe social e psíquica" (2007, posição 1711). Talvez por seu empenho em fazer um apanhado histórico e crítico sobre tema, a autora refira-se ao uso que Čapek faz da enfermidade coletiva como convencional e classifique sua ironia como primária. Entretanto, para os estudiosos mais aprofundados na obra do autor tcheco, essa questão não parece ser assim tão convencional, e sim mais uma demonstração de sua capacidade de incorporar as grandes questões sociais, filosóficas e morais de seu tempo ao seu trabalho ficcional.

Ivan Klíma $(2002$, p. 139) aponta como ponto forte da obra de Čapek a arte da fabulação, descrevendo-a como um talento que combina imaginação, coragem na criação de parábolas originais e capacidade de, através delas, pensar os problemas sociais e tecnológicos dos tempos modernos. Embora esse comentário pareça se aplicar mais às obras anteriores, é possível argumentar que, com o passar dos anos, Čapek não perdeu sua capacidade fabuladora. A mesma urgência que o fez retomar a escrita dramática, abandonada dez anos antes, pode ser pensada como uma das causas de, em $A$ doença branca, o escritor ter apelado a uma matéria mais simples e direta, ao invés de criar possibilidades fantásticas, como fizera em A fábrica de robôs, de 1920, ou no romance Guerra das Salamandras, de 1935. Para chegar a essa conclusão, levamos em conta o posicionamento antifascista do autor e a celeridade com que uma nova guerra se aproximava.

Ainda de acordo com Klíma, Karel Čapek foi um dos primeiros escritores no mundo a se posicionar publicamente, e de maneira 
muito acurada, contra a chegada de Hitler ao poder, quando ainda a maioria dos intelectuais e políticos democratas considerava a ascensão do nazismo como "meramente um episódio indigno de ser trabalhado" (2002, p. 187, tradução nossa) ${ }^{8}$. Em uma série de ensaios publicados em 1934, Čapek questiona não tanto os motivos políticos e econômicos que levaram aos acontecimentos na Alemanha, mas sim o papel das classes educadas daquele país: "[...] todo um Reich chegou, espiritualmente, acreditando no animismo, racismo e absurdos semelhantes; uma nação inteira, por favor, com professores universitários, padres, escritores, médicos e advogados" (ČAPEK apud KLIMA, 2002, p. 187, tradução nossa) $)^{9}$. Como pensador contemporâneo, o escritor não apenas avaliava o que estava acontecendo naquele exato momento na Alemanha, mas previa as consequências futuras que tais eventos trariam para todo o continente europeu. Na tentativa de chamar a atenção das classes intelectualizadas, tanto da Tchecoslováquia quanto no resto do mundo, a escrita de uma peça de teatro, com um motivo recorrente - a peste como metáfora para uma sociedade moralmente corrompida -, a despeito de parecer convencional para o estudo diacrônico dos usos da doença na literatura e nas artes, mostra-se de pontual e acertado impacto em seu tempo.

Para Petr Jemelka, a paisagem que se apresentava diante dos olhos de Čapek no período entreguerras, junto de sua consciência da gradual intensificação da crise de valores vigentes,

8 Do original, em inglês: "[...] merely an episode unworthy of getting worked up over".

9 Do original, em inglês: "[...] one whole Reich has come around, spiritually, to believing in animism, racism, and similar nonsense; an entire nation, if you please, with university professors, priests, writers, physicians, and lawyers". 
foi o que possibilitou a criação de obras literárias com humanismo atemporal, cujo valor artístico apoia-se sobre "uma notável base filosófica e apelo moral" (2019, p. 168, tradução nossa) ${ }^{10}$. De fato, uma leitura de $A$ doença branca hoje nos mostra que o drama, embora escrito em um contexto específico de espaço, tempo e acontecimentos singulares, mostra-se ainda bastante atual, não apenas pela temática, mas pelos questionamentos que possibilita.

A situação em si, de uma doença que se alastra pelo mundo há mais de três anos, sem que seja descoberta uma cura ou ao menos um tratamento para prolongar a vida dos infectados, e mesmo os diálogos entre as personagens, que em outros tempos poderiam soar um tanto absurdos, diante da atual situação de pandemia de covid-19, e dos desmandos políticos bem como da desinformação em torno do coronavírus, não pareceram ao leitor de 2020 nada insólitos e menos ainda fantásticos. Pelo contrário, se para o público tcheco - e mundial - de 1937 houve algum espanto ou estranhamento com a situação levada ao teatro, nos dias atuais nada nos parece mais verossímil.

\section{REFERÊNCIAS}

ČAPEK, Karel. A doença branca. Tradução de Leo Marten. Rio de Janeiro: Zelio Valverde Livreiro-editor, 1942.

ČAPEK, Karel. Histórias Apócrifas. 3. ed. Tradução de Aleksandar Jovanovic. São Paulo: Editora 34, 2013.

ČAPEK, Karel. Bílá Nemoc. E-kniha. Praha: Městská knihovna v Praze, 2018.

JEMELKA, Petr. Bioethical motifs in the literary work of Karel Čapek. Ethics \& Bioethics (in Central Europe), 9 (3-4), p. 168-180, 2019.

10 Do original, em inglês: "[...] supported by a remarkable philosophical base and moral appeal.". 
JíCHOVÁ, Jana. Etické aspekty vdíle Karla Čapka, zejména v dramatech Bílá nemoc a Matka. [Aspectos éticos da obra de Karel Čapek, especialmente nos dramas $A$ doença branca e A mãe.] Diplomová práce. Univerzita Karlova v Praze/Katolická Teologická Fakulta/Katedra teologické etiky a spirituální teologie. Praha, 2016. JOVANOVIC, Aleksandar. Introdução. In: TCHÁPEK, Karel. A fábrica de robôs. Tradução de Vera Machac. São Paulo: Editora Hedra, 2010.

KLÍMA, Ivan. Karel Čapek - Life and Work. Translated from the Czech by Norma Comrada. North Have: Catbird Press, 2002.

SONTAG, Susan. Doença como metáfora/AIDS e suas metáforas. E-book. Tradução de Rubens Figueiredo e Paulo Henriques Britto. São Paulo: Companhia das Letras, 2007.

TCHÁPEK, Karel. A fábrica de robôs. Tradução de Vera Machac. São Paulo: Editora Hedra, 2010. 